\title{
Morbus est... Roman Views on Health of Animals as a Basis for the Present-Day Warranty Legislation
}

\begin{abstract}
The aim of the study is to reveal the connections and inspirations between Roman and contemporary regulations of warranty, as an element of European heritage. The material for the study consists of Justinian's "Digest", Gellius' and Cato's works, contemporary Polish warranty legislation - the Civil Code, its amendments and executive acts. Juridical, medical and philosophical views of ancient Roman lawyers on animal health in the mentioned material were examined and analyzed. The views of the ancient Romans reflected in Polish civil law were pointed out. Studies have been carried out, comparing the ideas that provide the background for legal norms of warranty. It has been proved how different defining of health and disease in veterinary medicine can affect divergent legal regulations in relation to animals sold. The functionality criterion was affirmed to be applicable not only as one of warranty premises, but also as a motor for legal development.
\end{abstract}

Keywords: disease, illness, latent defects, history of veterinary law

Słowa kluczowe: choroba, wady ukryte, historia prawa weterynaryjnego

All animals bought can have latent defects. Nature or specific features particular to animals do not imply any kind of legal defectiveness. They can, however, manifest themselves in physical abnormalities. Such hidden illnesses occurred in Antiquity and still occur in the present-day commerce. It is the effect of cooperation of veterinary surgeons with lawyers and legislators, to prepare proper legal norms, that would act efficiently in market situations. One of the first problems to be solved is to define what a latent physical defect of an animal is - and thus, what an illness, a disease, a defect is. Legal definitions of such terms rely on firm medical and veterinary knowledge.

It was the ancient Romans who have developed for the first time in history the branch on knowledge known as medicina veterinaria or mulomedicina, ${ }^{1}$ they have also brought civil law to the heights of perfection. Roman lawyers often acted as commentators, but

\footnotetext{
1 Adams, Pelagonius and Latin, 312-3.
} 
their opinions were treated as legislation, and finally were compiled in the emperor Justinian's "Digest or Pandects". ${ }^{2}$ In the classical era [ca. 27 BC - 284 AC] they developed new definitions of health and diseases. Their views even today constitute a basis for legal norms of the Polish Civil Code. ${ }^{3}$ In order to interpret the aforementioned issue, Roman legal views on health and lack of it, jointly with modern concepts, are analysed in the present paper.

\section{Materials and Methods}

Materials subject to the present analysis are: legal texts of Justinian's "Digest" [D.], issued in $533 \mathrm{AC}$, and excerpts stored in the works of Aulus Gellius ${ }^{4}$ and Cicero. ${ }^{5}$ Ancient authors, opinions of whom are examined and analysed in the present paper, are: Cato, Cicero, Sulpicius Rufus, so-called veteres iurisperiti or iureconsulti, Sabinus, Labeo, Testa, Ofilius, Pedius, and Ulpian. The Polish Civil Code and its amendments, ${ }^{6}$ as well as the regulation on the main defects of certain animal species, ${ }^{7}$ were tested.

Historical and historical-legal methods were used for the examination and analysis of the ancient texts. For the inquiry into both Roman and Polish legal norms, the following methods of statutory interpretation were used: grammatical and comparative methods as basic interpretational rules, together with systematic, functional and teleological interpretation.

The paper describes the Roman influence on obligatory law of warranty, and does not focus on guarantee law, based on different stipulations and promises given voluntary by the vendor.

${ }^{2}$ Digesta, 21.1.

${ }^{3}$ Kodeks cywilny z 1964 r. (t.j. Dz.U. z 2019 r., poz. 1145, 1495).

${ }^{4}$ Gellius, Noctes Atticae, 4.2 .

${ }^{5}$ Cicero, Tusculanae disputationes, 4.13.28-19.

${ }^{6}$ Ustawa z dnia $2 l$ sierpnia 1997 r. o ochronie zwierząt (Dz.U. z 2013 r., poz. 856, z 2014 r., poz. 1794, z 2015 r., poz. 266, z 2016 r., poz. 1605, 1948, 2102); Ustawa z dnia 27 lipca 2002 r. o szczególnych warunkach sprzedaży konsumenckiej oraz o zmianie Kodeksu cywilnego (Dz.U. z 2002 r., nr 141, poz. 1176); Ustawa z dnia 30 maja 2014 r. o prawach konsumenta (t.j. Dz.U. z 2017 r., poz. 683, 2361, z 2018 r., poz. 650); see also for European law: Directive 1999/44/EC of the European Parliament and of the Council of 25 May 1999 on certain aspects of the sale of consumer goods and associated guarantees (EC Official Journal, L 171, 0012-0016); Directive 2011/83/EU of the European Parliament and of the Council of 25 October 2011 on consumer rights, amending Council Directive 93/13/EEC and Directive 1999/44/EC of the European Parliament and of the Council and repealing Council Directive 85/577/EEC and Directive 97/7/EC of the European Parliament and of the Council (EU Official Journal, L 304/64). Cf. Lubelska-Sazanów, „Odpowiedzialność”, 21-41; Zoll, Rękojmia, 1, 4-5, 7-11, 13-14, 17, 20, 22-35, 48-51, 54-56, 66-99, 105, 108-10, $156-64,321-49$.

${ }^{7}$ Rozporzadzenie Ministra Rolnictwa z dnia 7 października $1966 \mathrm{r}$. w sprawie odpowiedzialności sprzedawców za wady główne niektórych gatunków zwierząt (Dz.U. z 1966 r., nr 43, poz. 257). 


\section{Roman Conceptions' Starting Point}

The basis for ancient jurists' commentaries were two edicts of the curule Aediles, officials responsible for urban police ${ }^{8}$ and commerce. The first edict referred to slaves [edictum aedilium curulium de mancipiis emundis vendundis], the latter to animals [edictum aedilium curulium de iumentis vendundis], preserved in Justinian's "Digest" 21.1.38.pr., 21.1.38.5, and Gellius' "Attic Nights" 4.2. These acts formed one legal system in which animals and slaves were treated almost identically. Also the jurists' opinions can be related unanimously and colinearly to these two groups of goods in most cases. ${ }^{9}$

The norms concerned, i.a. warranty for latent defects in animals, manifesting in the morbus vitiumve - diseases and ailments. Detection of latent defects gave the purchaser the right to rise against the seller a redhibitory action [to return of the goods], or to reduce the price [using an action called quanti minoris, or quanto minoris, or aestimatoria]. Aedilician law was in force not only as long as the Roman Empire existed, but also in the further centuries - as ius commune, supplementary, pan-European, "common" law. On this basis almost all 19th-, 20th-, and 21st-century civil legislations were created. These concepts are full of life and vigor, even despite the on-going change in the definition of warranty for physical defects for liability for lack of conformity with the contract, observed in the current European [both sensu stricto and sensu largo] law.

However, the Aedilician law itself did not define the concept of health [sanitas, or sanum esse], disease [morbus, or non esse sanum], and defect [vitium], leaving this to the jurisprudence. It should be observed that modern Polish civil law continues this manner, but with an essential difference - present-day judicature or doctrine cannot create legal rules, as the Roman jurisprudence did. The technical terms found in the Aedilician edict, were contemplated and commented upon by various Roman lawyers over the years and ages, and numerous and often mutually exclusive examples of ideas arose.

\section{Divergence of Opinions}

It should be stated that only a few of the presented views could be considered as definitions in the modern sense of the word. Roman lawyers were particularly reluctant to provide any definitions. Likewise, most of the ancient medicals adopted these conceptions only intuitively.

Firstly, duality of terms morbus and vitium should be considered. ${ }^{10}$ At the early stage the semantic difference was firmly emphasised and legal concepts focused on difference between a disease and a defect, what has been described by authors such as Aulus

\footnotetext{
8 Jakab, "Praedicere und cavere”, 49-296; Kuryłowicz, "Działalność karno-administracyjna”, 65-78; Kuryłowicz, "Zur Marktpolizei", 439-56; Nippel, Aufruhr und "Polizei”, 27 ff.

9 Talamanca, "Trebazio Testa", 62-3.

10 Vincent, Le droit, 37-40; Arangio-Ruiz, La compravendita, 333-7, 355, 385-6; Manna, Actio redhibitoria, 26, 34-5, 37, 39, 40-2; Ortu, “Aiunt aediles ... ”, 95-101, 112-20, 124, 134-5, 142, 161-2.
} 
Gellius. In the following centuries, the difference was of marginal importance, and the two terms analyzed were understood as one medical-legal concept, covering the whole scale of various infirmities. ${ }^{11}$ It should be noted that ancient understanding of health can only be shown by opposition to concepts of illness. Secondly, the definition of "nature" or "natural state" shall be considered, as it covered a relevant part of health for many of the ancient authors. In the next part of the paper, consecutive views of Roman authors will be researched, analyzed and presented.

Cato $^{12}$ stated that if a finger or a toe is cut, this state shall be considered as a disease. Although this is only a casuistic opinion, a general rule can be derived from it, opposite to the conclusions reached by the veteres: according to Cato, a permanent physical injury creates a disease.

In Cicero's opinion, ${ }^{13}$ as a disease can be classified only the corruption or infirmity of the entire animal body (totius corporis corruptio), while vitium touches only one part of the body afflicted with a defect, e.g. limb.

Variety of opinions, classifications and arguments can be presented by the following example: Servius Sulpicius Rufus vs. Marcus Antistius Labeo and Paulus. The first of the mentioned authors revealed - according to Gellius ${ }^{14}$ - the most extreme view: every, even the lightest and most trivial disorder, such as a missing tooth, was sufficient to claim the return of an animal. Servius was in favour of the buyers. His proposal of extraordinarily broad redhibitory rights was based, most likely, on the contractual fides. ${ }^{15}$ Sulpicius Rufus definitely did take into account neither the utility criterion nor the economic aspects, ${ }^{16}$ and nor rational pragmatism. As a consequence, his radical and absurd (as revealed both by Gellius and in the Justinian's codification) doctrine remained solitary and was abandoned in the later years. The opposite view was presented by Labeo and followed by Paulus ${ }^{17}$.

Application of a temporal criterion is attributed by Gellius ${ }^{18}$ to the group of unknown lawyers, referred to as the veteres iurisperiti. They supposedly were of the opinion that vitia last continuously, while morbi access and decease (dynamic disease conception). Probably they should have paid more attention to permanent ailments than to severe, but transitional illnesses. ${ }^{19}$ For hundreds of years their idea was desolated, supported only by Modestinus and Nonius Marcellus. ${ }^{20}$ The opinions of the veteres were eclipsed by Labeo's theory, expressed at the same time - at the turn of the Republic and the Principate. Different legal orientation on jurists was revealed in divergent sentences.

${ }^{11}$ Manna, Actio redhibitoria, 26, 34-5, 37, 39-2; Ortu, “Aiunt aediles ...”, 95-101, 112-20, 124, 134-5, $142,161-2$.

${ }^{12}$ D. 21.1.10.1.

${ }_{13}$ Cicero, Tusculanae disputationes, 4.13.28-19.

${ }^{14}$ Gellius, Noctes Atticae, 4.2.12.

${ }^{15}$ Ortu, “Aiunt aediles...", 95-101, 112-20, 124, 134-5, 142, 161-2.

16 Manna, Actio redhibitoria, 39-2.

${ }^{17}$ D. 21.1.11.

18 Gellius, Noctes Atticae, 4.2.2.

${ }^{19}$ Lanza, "D.21.1: de res se moventes", 74-81.

${ }^{20}$ D. 50.16.101.2 and Marcellus, "De compendiosa", 5.32, vol. 3, p.708L. 


\section{Birth of the Functionality Criterion Concept}

The propositions of Aulus Ofilius, preserved in the "Pandects", ${ }^{21}$ contain indirect, functional definitions of an illness, which can be derived from casuistic examples of a horse with a cut-off tongue, and of a slave with an injured finger or limb. In Ofilius' opinion such a horse or such a slave was of diminished usefulness (minus uti possit) and unhealthy (non esse sanum, potentially touched with morbus as well as with vitium). He showed, in a veiled manner, the criterion of economic functionality of goods. His commentaries were presented with the aim to create good laws taking into consideration the utility limits of objects to the contract of sale. ${ }^{22}$ As a side-note, it should be observed that in horse tongue bears many important functions and therefore, its injury would firmly decrease the functionality of the animal considered. Contrary statements, ${ }^{23}$ denying the application of the functionality criterion, incorrectly assume that tongue is only a speechenabling tool particular to men [i.e. slaves], and has no other proprieties in animals.

Another type of argumentation regarding the discussed phenomenon was presented by Trebatius Testa, ${ }^{24}$ who defined health in a negative manner, as a physical state opposite of a disease - non esse morbosus, and assumed a disease is an open set of various medical perturbations. He indicated two simultaneous criteria of return / price reduction admissibility: firstly, decrease of the economic utility, and secondly, occurrence of a physical pathology classified ad casum as a disease.

Trebatius drew his attention to the difference of congenital and acquired bodily defects, and it was only he among the Roman jurists that considered this division to be legally relevant. He understood natural state subjectively for each particular individual and therefore excluded any return claims in cases of congenital perturbances like innate sterility. According to Testa, ${ }^{25}$ the natural state of a particular individual was to have been born with or without certain abilities or proprieties, and that this state remained the only-possible experience, in contrast to acquired infirmities, where the natural state has been disturbed or damaged. This opinion is not shared by the modern law.

\section{Ways to Juridical Synthesis}

Labeo followed [critically and not word for word] and expanded Ofilius and Testa's theories, ${ }^{26}$ providing the only complete, general, abstract, functional answer to the question "What an illness is?", that can found in Roman legal sources: ${ }^{27}$ Morbus est habitus

\footnotetext{
21 D. 21.1.8, 21.1.10.pr.

${ }^{22}$ Lanza, D.21.1, 74-81.

23 Ortu, “Aiunt aediles...”, 95-101, 112-20, 124, 134-5, 142, 161-2.

${ }^{24}$ D. 21.1.6.1, 21.1.12.4.

25 D. 21.1.14.3. Gellius, Noctes Atticae, 4.2.6-10.

26 Ibid.

27 Monier, La garantie, 33-36, 127-129; Monier, "La position”, 443 ff.
} 
cuiusque corporis contra naturam, qui usum eius facit deteriorem. ${ }^{28}$ According to Labeo, following conditions must be fulfilled: the occurrence of a particular physical state of any part of a body, and opposition of this state to nature [with an idealistic, objective, general, a priori definition of "nature" as "health", a state typical of entire species, independent of individual proprieties, being therefore an example of a negative and objectivising view], and a causally-connected deterioration of animal's utility and ability to work. ${ }^{29}$

In contrast to his master Trebatius, Labeo permitted return of goods such as animals [pigs] and men [slaves] in any cases of sterility, both congenital and acquired, stating that it cannot be consistent with general natural regularity. In this narration of Labeo, continued later-on by Caelius Sabinus, ${ }^{30}$ also the mutual relations of morbus and vitium can be described with diseases being subordinate ${ }^{31}$ and subtype to more general category of defects [vitia]. Every illness is therefore a defect, but not every defect is a disease. ${ }^{32}$ The concept of disease in this variation can be seen as an increasing pathological phenomenon, while an anatomic or physiological imperfection can be understood as a defect both being and not being a disease..$^{33}$

Regardless of aboriginal practical ${ }^{34}$ or theoretical ${ }^{35}$ approach of his ideas, and although there are no slaves today, Labeo's concepts were [probably] subsequently adopted by Paulus and a majority of Roman jurists. ${ }^{36}$ According to his opinion, only the objective diminution of value, arising from the occurrence of a physical defect, was an important factor for return or price-reductory claims. His opinion has been shared by legislators of the subsequent centuries and are still applicable in modern doctrine of civil law.

Masurius Sabinus ${ }^{37}$ was another votary of the functionality criterion, expressed by a phrase: quo ipse minus aptus sit. In the same time, he denied congenital defects are diseases, and mixed concepts of Labeo and Trebatius.

Sextus Pedius ${ }^{38}$ expanded the discussed idea and introduced the term ministerium, i.e. a scope of proper usage of particular types of goods in accordance with the intention of the parties to the contract of sale. Possibility of proper use of an animal in accordance with its ministerium, was tantamount to state of health, and excluded any legal claims, in spite of an illness or a defect. This new point of view put emphasis on the utility decrease due to a disease as a redhibitory indicator. It should be noted that his understanding of health is strictly a legal and not a medical one, but it put an impact on the present-day practice.

Ulpian ${ }^{39}$ compared and synthesised all the aforementioned concepts into a common, general category of bodily defects [vitia corporis], covering both morbi and vitia. Ulpian

28 Gellius, Noctes Atticae, 4.2.3-4.

29 Ortu, "Aiunt aediles...", 95-101, 112-20, 124, 134-5, 142, 161-2.

30 D. 21.1.38.7; Gellius, Noctes Atticae, 4.2.5.

31 Lanza, D.21.1, 74-81.

32 Gellius, Noctes Atticae, 4.2.5.

33 Arangio-Ruiz, La compravendita, 333-7, 355, 385-6.

${ }^{34}$ Lanza, D.21.1, 74-81.

35 Vincent, Le droit, 37-40.

${ }^{36}$ Gellius, Noctes Atticae, 4.2.13-14. Lanza, D. 21.1; Monier, La garantie; Ortu, “Aiunt aediles...”.

37 Gellius, Noctes Atticae, 4.2.15; D. 21.1.14.pr.

38 D. 21.1.12.1, 21.1.14.4-5.

${ }^{39}$ D. 21.1.1.7 in fine, 21.1.1.8, 21.1.1.10, 21.1.4.3-4. 
also mixed the Labeonian usus with the Pedian ministerium. ${ }^{40}$ Animal and slave usefulness were for Ulpian the possibility for the correct use in scope of the ministerium and the use intended by the parties.

The functionality criterion was made more general and abstract, much more than vitium or morbus themselves, than the group-category of physical abnormalities, than the concept of the "natural state". Focus of juridical thought shall no longer be on a disease and its relation to the nature, but on the maintenance or deterioration of the proper usefulness and financial value, and on the parties' intention.

\section{[Un]necessity of the Modern Defining Efforts}

It should be observed that neither modern veterinary or human medicine, nor legal science, has developed any uniform and consistent definitions of health or disease. There are many various and often exclusive types of definitions, among which attributive biological, biological-functional, functional, naturalistic, negative, nominalist, normative, objectivising, positive, realistic, relational, subjective, and other ones can be found. ${ }^{41}$ It is estimated that over 120 such definitions exist. The inability to develop unambiguous definition results from its different application in biology, medicine, law, psychology or sociology, as well as the fact that these conceptions bear a burden of axiological, cultural, ideological background, and socio-economic and political influence. ${ }^{42}$

As there is no strictly veterinary definition of health issued by official medical authorities, the question arises if the human World Health Organization's statement can be used auxiliary and subsidiary?

"Health is a state of complete physical, mental and social well-being and not merely the absence of disease or infirmity" ${ }^{43}$ This WHO's opinion is highly disputable and is criticised for lack of precision, too excessive inclusivism, inflexibility or mixing health with happiness. In the light of the current veterinary knowledge, only some of the mentioned objections could apply to animals. In the author's opinion, this holistic, positive and subjective definition of health could be used in veterinary medicine, but with the proper restrictions resulting from the differences between men and animals, and taking into account modern concepts of animal welfare ${ }^{44}$. As for animals, health in the WHO's way can be understood as a state of absence of disease or infirmity, combined with the state of complete animal welfare. According to it, animal health should be rated in a subjective and interdisciplinary way. This concept is not based in the presented antic ideas, but rather in the relative new view, connected with the development of medicine, psychology and animal behaviouristic studies. Can this opinion on health be used for

40 D. 21.1.1.8.

41 Domaradzki, „O definicjach”, 5-29.

42 Dolfman, "Toward operational", 206-9; Engelhardt, "Ideology", 256-68; Hofmann, "Complexity”, 211-36.

43 World Health Organization: The Preamble of the Constitution of the World Health Organization. WHO Off. Rec. 1946, 2, 100.

44 Fraser, Weary, Pajor, Milligan, "A scientific”, 187-205. 
estimation in legal claims? According to the author, it can - but only as a sign-post. Each physical state should be assessed separately.

A more important question to be asked is: does the Polish warranty law use and need the concept of health and disease at all? Absolutely. However, it is used in a different way than in the Roman law. Therefore, these ideas do not need to be defined to discuss the presence of warranty for animal lack of health in Polish legal system.

\section{Current Polish Law of Warranty - Preliminary Observations}

Although the Animal Protection Act ${ }^{45}$ states that animals are not things, this does not apply to commerce and civil law, in scope of which all animals are without any doctrinal or judicial doubt treated as things, and thus as goods of sale. ${ }^{46}$

The complicated history of Poland during the partitions and after the 1918 regain of independence resulted in various legal systems in force. ${ }^{47}$ Nonetheless, it should be stated that warranty responsibility in European 19th- and 20th-century codifications has been modelled after Roman contrivances and improved through generalization. ${ }^{48}$ One should remember, that there was no reception of Justinian's law in Poland, as in case of Germany, and that our civil law gained legal institutions and was inspired via divergent civil codes, such as Austrian, French, German, or Swiss. Modern Polish legal history of animal health-based warranty begins with the publication of the 1964 Civil Code [in force since January 1st, 1965] and the regulation on the main defects of certain animal species [in force 1966-2014], changed firmly in 2002, and in 2014 for the sake of consumer rights and European legal unity [but not uniformity]. With the revocation of lex specialis concerning the "major defects", the transformed and deeply re-arranged Aedilician rules, developed for animals and slaves, are applicable to animals again - although this is not a perfect system.

Assessment of the presence of a physical defect is made according to objective values. This view can be derived directly from art. 556-576 ${ }^{4}$ of the Civil Code, using the grammatical interpretation: an animal can be healthy or can be burdened with defects [diseases or infirmities of different nature], tertium non datur.

${ }^{45}$ Ustawa z dnia $2 l$ sierpnia 1997 r. o ochronie zwierząt (Dz.U. z 2013 r., poz. 856, z 2014 r., poz. 1794, z 2015 r., poz. 266, z 2016 r., poz. 1605, 1948, 2102).

${ }^{46}$ Goettel, Sytuacja zwierzęcia, 132-149.

${ }^{47}$ Falkowska, Odpowiedzialność sprzedawcy, 27-312.

${ }^{48}$ Zimmermann, Roman law, 121-123. 


\section{Functionality Criterion in the Polish Law as Indirect Roman Inheritance - A comparative Perspective}

Polish civil definition of a physical defect is broader than the Roman, and is defined as a discordance, incompatibility, inconformity of physical features of a particular good of sale with the contract. Among physical defects various types can be found, e.g. diminishing the price / value of an animal, diminishing its utility [basing on the conventional aim intended by the parties, or on the appropriated aim, or as the case circumstances require]. Polish law adopts the late Roman concept, according to which there is no legal difference between various types of lack of health [disease, ailment, malformation, congenital or acquired illness, etc.], and redefines its application also for other kinds of physical defects.

Apart from health perturbations, in both Roman and Polish civil law, responsibility of the seller for his stipulations [such as race pattern, amount of aggression or fear, milking or nursing capacity], and for improper contract performance, for lack of contract fulfilment, for an error, as well as contractual and delictual responsibility for delivery of a defective animal, can be observed. ${ }^{49}$ The purchaser and vendor have in modern Poland, according to art. 560-561 of the Civil Code, wider possibilities of action than in the ancient Rome or in the modern German law. ${ }^{50}$ Also the 2014 novelisation increased sellers' liability in consumer sales. ${ }^{51}$

At first glance, it may seem that due to the idea of [non]conformity with the contract there is nothing left of the old concepts, and neither the typical physical defect nor its particular form - the disease of an animal - has any legal significance anymore. This is, however, a wrong impression, resulting from a lack of in-depth analysis and lack of understanding of the practical aspect of the problem discussed. Using a word-play one could state, that such an opinion could be assessed as the lack of conformity with the law-it-action.

Application of the functionality criterion can be derived from art. $556^{1} \mathrm{ff}$. of the Civil Code. Only these states of lack of health that lower animal's value or usefulness, are defined as defects and result in civil responsibility. An ill animal is defective if its infirmities prohibit the proper usefulness, intended and declared in the contract or appropriated by the parties, or required by circumstances. Labeonian and Pedian views eclipsed problematic sanitas, in favour of measurable deterioration of functional and financial value.

It can be concluded that not the health state itself is relevant in Polish law, but the concordance and conformity of the health state [or other factors] with the contract of sale. This view is closer to the Aedilician obligation of palam recte pronuntiare / dicere mixed with concepts growing from the late-classic regime of Aedilician responsibility for dicta

49 Goettel, Sytuacja zwierzęcia, 132-49.

50 Zimmermann, The law, 305-36; cf. Zoll, Rękojmia, 2, 38-48, 50, 53, 99.

51 Lubelska-Sazanów, „Odpowiedzialność”, 21-41; Ustawa z dnia 30 maja 2014 r. o prawach konsumenta, (Dz.U. z 2017 r., poz. 683, 2361, z 2018 r., poz. 650; Zoll, Rękojmia, p. 4, 8-9, 20, 22-35, 50, 54-6, $105,108-110,321)$. 
promissave. ${ }^{52}$ The letter clause stated that the vendor who, in spite of the legal obligation to disclose the defect, would knowingly avoid this declaration, was responsible for all the defects, regardless of other factors. The basis of seller's liability in the analyzed case was the existence of a disease, and not lack of its declaration. Not the occurrence of physical infirmities implied the seller's responsibility, but his failure to fulfill his duty. In case of declared defects no liability had existed, for the counterpart did have full knowledge on the animal bought. Dicta extended Aedilician responsibility on any hidden defects (but not patent), regardless of the good or bad will of the seller, or his knowledge or ignorance. Similarly, in the Polish rules, not the occurrence of a disease itself creates vendor's liability, but the fact that the defect most presumably existed prior to sale and was hidden to the purchaser, ${ }^{53}$ and is based on risk, regardless of fault. ${ }^{54}$

Nevertheless, not every illness can be evaluated unanimously in all cases ${ }^{55}$ and the assessment ought to be made ad casum. Appointment of a veterinary expert could be necessary. ${ }^{56}$

\section{Level of Relevance of a Defect}

A different criterion is used when assessing the level of relevance of the particular defect [in each case] - a subjective one. This grading enables one to distinguish defects into relevant and irrelevant, and that put an impact on the seller's liability - the occurrence of an irrelevant defect extenuated responsibility and restricted the purchaser's right to renounce a contract of sale, according to art. $560 \S 4$ of the Civil Code. According to juristic views, ${ }^{57}$ the discussed defect's significance estimation cannot be performed using objective factors. In this regulation, Trebatius Testa's influence can clearly be seen.

Functionality criterion based on possibility of a normal use shall be therefore excluded in this case. This opinion was not absolute, and even its advocates ${ }^{58}$ stated that all the "major defects" [legal category existing in Poland till 2014], shall be treated as relevant ones. It should be noted that use of subjective criteria for defect's relevance estimation does not mean applying subjective definition of health and disease. It is rather a subjective, casuistic way of enquiring in each particular case factors like, i.a. animal species, race, sex, age, intended use and value, to see how the defect lowered functional and economic usefulness of a particular animal. Level of relevance is also important for estimatory claims - reduction of price. If the rating of value diminish [economic or functional] is not possible, the purchaser cannot use this right. ${ }^{59}$

52 Impallomeni, L'editto, 6-7, 210; Jakab, “Praedicere”, 49-296; Monier, La garantie, 33-36, 127-29; Vincent, Le droit, 37-40.

${ }_{53}$ Zamir, "Toward a general", 4-90.

${ }^{54}$ Lubelska-Sazanów, „Odpowiedzialność”, 21-41; Podrecka, Rękojmia za wady, 27-39, 51-69; Zimmermann, The law, 305-36.

${ }_{55}$ Zieliński, „Rękojmia za wady”, 104.

${ }^{56}$ Babińska, Szarek, Naumowicz, Felsmann, Sołtyszewski, Dzikowski, „Wady fizyczne”, 276-9.

57 Żuławska, Komentarz do tyt. XI dz. II, 74-77; Goettel, Sytuacja zwierzęcia, 132-49.

${ }^{58}$ Ibid.

${ }^{59}$ E.g. Supreme Court judgment: III CZP 11/77, OSNCP 1977, No. 8, pos. 132. 
An illness in the modern civil law is one of the circumstances rated, and many other factors must occur to conclude that a particular state is a physical defect of an animal. But the main impact is put on other criteria, like economic / functional criterion of diminishing value or usefulness of an animal. ${ }^{60}$ The disease concept is only subsidiary. Modern warranty rules adopt some of the ideas of Ofilius, Pedius, Labeo and Ulpian, but change them to more general and more efficient system. This is a paradoxical effect of Roman authors' disputes on health.

\section{Conclusions}

What is an illness? - this question seems to be the most relevant for determining what a physical defect is. But history of legal ideas reveals, that neither any possible answer given, nor the inquiry itself can be admitted correct. Pliny the Elder ${ }^{61}$ wrote ironically that no art is so inconstant and highly-mutable as medicine, and that no-other is so necessary. Nowadays one can say that this is a true statement also for law, so often - too often - amended.

Centuries passed as veterinary medicine developed, and physicians often changed [and change] their views on diseases, etiology, therapeutic methods - alike the legal views change, and still cannot arrive at a compromise over what health actually is. Along with the development of veterinary and legal science, new questions and doubts arise. Not only in terms of health and disease, but also concerning what a physical defect is, or rather: what it can be made to be.

It should be concluded that the criteria applied by both Roman and modern jurists serve as conditions for the admissibility of legal claims arising in case of animals afflicted with latent defects. Definitions of health and disease are only secondary, subsidiary, and subordinate. Their role is to prove whether a particular animal could still be used in accordance with its correct function and the parties' intention. On the basis of Roman casuistic contemplations, general rules were built, allowing to objectivise the assessment of the admissibility.

Preserved Roman pre-definitions make use of ancient medical and veterinary knowledge, as well as apply considerations of a philosophical nature - to practical purpose. Economic interests of purchasers prevailed the initial caveat emptor rule and progress the juridical thought. Applying the functionality criterion enabled lawyers to produce general rules in which a defect is much more than a disease itself.

The mentioned phenomenon is highly current in contemporary veterinary medicine and law.

Indirect reception of the ancient rules created by the curule Aediles and transformed by divergent jurists' opinions and further centuries' experience, with favour of the purchaser's interests, produced modern warranty regulations. An opinion could be asserted, that the Polish model of warranty law, despite of and owing to the slight deviation

${ }^{60}$ Zimmermann, The law, 305-36.

${ }^{61}$ Plinius, Naturalis Historia, 29.2. 
from pure Roman tradition, functionally better fulfils the same pragmatic premises the Romans wanted to achieve.

Definitions of health depend on the circumstances and intentions of their authors, and still change. The same is true for the warranty concept of defect - or [non]conformity with the contract. Practical application of legal norms forces modern legislators and judges to rely on a firm veterinary knowledge to determine what is and what is not an illness, a defect and nonconformity. Adoption of a legal definition of health or illness would be ineffective and inconvenient. Not the definition itself is crucial, but the practical application of legal norms and veterinary medicine in a particular case.

\section{Bibliography}

\section{Sources}

Cicero, Marcus, Tulius. “Tusculanae disputations”. In M. Tullii Ciceronis Tusculanarum disputationum, ed. by Raphaël Kühner. Jena: typis et sumptibus Friderici Pormmann, 1853.

"Digesta seu Pandectae Iustiniani Augusti”. In Corpus Iuris Civilis I, ed. by Theodor Mommsen, Paul Krüger. Berolini: apud Weidmannos, 1872.

Gellius, Aulus. "Noctes Atticae". In Le Notti Attiche IV V. Introduzione, testo Latino, traduzione e note Franco Cavazza. Bologna: Bologna Zanichelli, 1985.

Marcellus, Nonius. "De compendiosa doctrina libros vicesimum”. In Nonii Marcelli De compendiosa doctrina libros XX, ed. by Wallace Martin Lindsay. Oxford: 1913.

Plinius, Secundus, Gaius. Naturalis Historia, ed.by Detlef Detlefsen. Berlin: Weidmann, 18661873.

Directive 1999/44/EC of the European Parliament and of the Council of 25 May 1999 on certain aspects of the sale of consumer goods and associated guarantees, EC Official Journal, L 171, p. 0012-0016.

Directive 2011/83/EU of the European Parliament and of the Council of 25 October 2011 on Consumer Rights, Amending Council Directive 93/13/EEC and Directive 1999/44/EC of the European Parliament and of the Council and Repealing Council Directive 85/577/EEC and Directive 97/7/EC of the European Parliament and of the Council, EU Official Journal, L 304/64.

Ustawa z dnia 23 kwietnia 1964 r. - Kodeks cywilny, Act of April 23, 1964, the Civil Code (t.j. Dz.U. z 2019 r. poz. 1145, 1495).

Ustawa z dnia 21 sierpnia 1997 r. o ochronie zwierzat, Act of August 21, 1997, on the Protection of Animals (Dz.U. z 2013 r. poz. 856, z 2014 r. poz. 1794, z 2015 r. poz. 266, z 2016 r. poz. $1605,1948,2102)$.

Ustawa z dnia 27 lipca 2002 r. o szczególnych warunkach sprzedaży konsumenckiej oraz o zmianie Kodeksu cywilnego, Act of July 27, 2002, on Special Conditions of Consumer Sales and Amendment the Civil Code (Dz.U. z 2002 r., nr 141, poz. 1176).

Ustawa z dnia 30 maja 2014 r. o prawach konsumenta, Act of May 30, 2014, on Consumers' Rights (t.j. Dz.U. z 2017 r. poz. 683, 2361, z 2018 r. poz. 650).

Rozporządzenie Ministra Rolnictwa z dnia 7 października 1966 r. w sprawie odpowiedzialności sprzedawców za wady główne niektórych gatunków zwierzą, Regulation of the Minister of Agriculture of October 7, 1966, on the Sellers' Liability for Major Defects of Certain Animal Species (Dz.U. z 1966 r., nr 43, poz. 257). 
World Health Organization: The Preamble of the Constitution of the World Health Organization. WHO Off. Rec. 1946, 2, 100.

Supreme Court judgment: III CZP 11/77, OSNCP 1977, No. 8, pos. 132.

\section{Literature}

Adams, James, Noel. Pelagonius and Latin Veterinary Terminology in the Roman Empire. LeidenNew York-Köln: E.J. Brill, 1995.

Arangio-Ruiz, Vincenzo. La compravendita in diritto romano, II. Napoli: Jovene, 1956.

Babińska, Izabella and Szarek, Józef and Naumowicz, Karolina, Felsmann, Mariusz, Z. and Sołtyszewski, Ireneusz and Dzikowski, Andrzej. „Wady fizyczne i prawne zwierząt w świetle aktów normatywnych". Medycyna Weterynaryjna 74 (2018): 276-9.

Dolfman, Michael. "Toward Operational Definitions of Health". Journal of the School Health 44 (1974): 206-209.

Domaradzki, Jan. „O definicjach zdrowia i choroby” On Definitions of Health and Illness. Folia Medica Lodziensia 40/1 (2013): 5-29.

Engelhardt, Hugo, Tristram. "Ideology and Etiology". Journal of Medicine and Philosophy 3/1 (1976): 256-68.

Falkowska, Anna. Odpowiedzialność sprzedawcy z tytulu rękojmi za wady fizyczne rzeczy, Seller's Warranty Responsibility for Physical Defects. Warszawa: Oficyna a Wolters Kluwer business, 2010.

Fraser, David and Weary, Daniel M. and Pajor, Ed and Milligan, Barry, N. "A Scientific Conception of Animal Welfare That Reflects Ethical Concerns". Animal Welfare 6 (1997): 187-206.

Goettel, Mieczysław. Sytuacja zwierzęcia w prawie cywilnym, Animal Status in the Civil Law. Warszawa: LEX, 2013.

Hofmann, Bjørn. "Complexity of the Concept of Disease as Shown through Rival Theoretical Frameworks". Theoretical Medicine and Bioethics 22/3 (2001): 211-36.

Impallomeni, Giambattista L'editto degli edili curuli. Padova: Cedam, 1955.

Jakab, Éva. "Praedicere” und "cavere” beim Marktkauf. Sachmängel im griechischen und römischen Recht. München: Beck, 1997.

Kuryłowicz, Marek. “Zur Marktpolizei der Römischen Ädilen”. In Au-delà des frontières. Mélanges de droit romain offerts à Witold Wołodkiewicz, I, ed. by Maria Zabłocka, Jerzy Krzynówek, Jakub Urbanik, Zuzanna Służewska, 439-456. Warszawa: Liber, 2000.

Kuryłowicz, Marek. „Działalność karno-administracyjna edylów rzymskich w sprawach handlowych" Penal and Administrative Activity of the Curule Aediles in Commerce. Zeszyty Naukowe Uniwersytetu Jagiellońskiego. Prace Prawnicze 125 (1989): 65-78.

Lanza, Carlo. "D.21.1: de res se moventes e morbus vitiumve": Studia et documenta historice et iuris 70 (2008): 55-163.

Lubelska-Sazanów, Małgorzata. „Odpowiedzialność z tytułu rękojmi za wady fizyczne przy sprzedaży zwierząt” Warranty Responsibility for Physical Defects of Animals Sold. Transformacje Prawa Prywatnego 4 (2015): 21-41.

Manna, Lorena. Actio redhibitoria e responsabilità per vizi della cosa nell'editto de mancipiis vendundis. Milano: A. Giuffrè, 1994.

Monier, Raymond. La garantie contre les vices cachés dans la vente Romaine. Paris: París Recueil Sirey, 1930.

Monier, Raymond. "La position de Labéon vis à vis de l'expression "morbus vitiumve" dans l'Édit des Édiles". Eos. Commentarii Societatis Philologee Polonorum 48 (1956): 443-448.

Nippel, Wilfired. Aufruhr und "Polizei" in der römischen Republik. Stuttgart: Klett-Cotta, 1988. 
Ortu, Rosanna. “Aiunt aediles...” Dichiarazioni del venditore e vizi della cosa venduta nell'editto de mancipiis emundis vendundis. Torino: Giappichelli, 2008.

Podrecka, Małgorzata. Rękojmia za wady prawne rzeczy sprzedanej, Warranty for legal defects in sales. Warszawa: LexisNexis, 2011.

Talamanca, Mario. "Trebazio Testa fra retorica e diritto". In Questioni di giurisprudenza tardo-repubblicana. Atti di un seminario, Firenze 27-28 maggio 1983, ed. Gian Gualberto Archi, Milano: Giuffrè Editore, 1985.

Vincent, Henri. Le droit des édiles. Etude historique et économique des prescriptions édiliciennes sur la vente et la garantie. Paris: Recueil Sirey, 1922.

Walker, Robin E. "Roman Veterinary Medicine". In Animals in Roman Life and Art., ed. by Jocelyn M.C. Toynbee, 312-314, New York: Ithaca, N.Y., Cornell University Press, 1973.

Zamir, Eyal. "Toward a General Concept of Conformity in the Performance of Contracts". Los Angeles Law Review 52 (1999): 4-90.

Zieliński, Czesław „Rękojmia za wady fizyczne zwierząt w obrocie powszechnym i uspołecznionym”. Państwo i Prawo 6 (1975): 103-110.

Zimmermann, Reinhard. Roman Law, Contemporary Law, European Law: The Civilian Tradition Today. Oxford: Oxford University Press, 2001.

Zimmermann, Reinhard. The Law of Obligations: Roman Foundations of the Civilian Tradition. Cape Town-Wetton-Johannesburg: Juta \& Co.,1990.

Zoll, Fryderyk. Rękojmia. Odpowiedzialność sprzedawcy. Warszawa: Wydawnictwo C.H. Beck, 2018.

Żuławska, Czesława. „Komentarz do tyt. XI dz. II”. In Komentarz do kodeksu cywilnego. Ksiega trzecia. Zobowiązania, II. Gerard Bieniek, Helena Ciepła, Stanisław Dmowski, Jacek Gudowski, Krzysztof Kołakowski, Marek Sychowicz, 74-77. Warszawa: LexisNexis, 2011. 